Original Article

\title{
Applying the "Pull-push" Theory in the Study of the Current Free Labour Migration from Rural to Urban Areas for Jobs in Vietnam
}

\author{
Nguyen Dinh Tan* \\ Ho Chi Minh National Academy of Politics, 135 Nguyen Phong Sac, Cau Giay, Hanoi, Vietnam \\ Received 26 September 2019; \\ Accepted 30 September 2019
}

\begin{abstract}
The "pull-push" theory is a theory that has been tested and applied to many studies of migration. According to a number of studies, there are many factors that motivate migration. However, the pull - push theory is still a comprehensive factor that influences other factors. Studies of free labour migration from rural to urban areas looking for jobs in Vietnam are not an exception. It is the "pull" forces of the destination and the "push" forces of the departure places where local people face many difficulties, have created the movement of population in society. This is as old as the hills, requiring the Party leaders at all levels and authorities to have the right recognition and appropriate behaviour. The most appropriate solution to the problem of the current migration in all its forms is to promote the process of industrialization and modernization in order to narrow the gap between regions, towards a harmony, fair, and wealthy society for all people.
\end{abstract}

Keywords: Migration, rural-urban migration, "pull-push", industrialization, institutional innovation.

\footnotetext{
*Corresponding author.

E-mail address: nguyenanhtanxhh@ gmail.com
}

https://doi.org/10.25073/2588-1116/vnupam.4198 


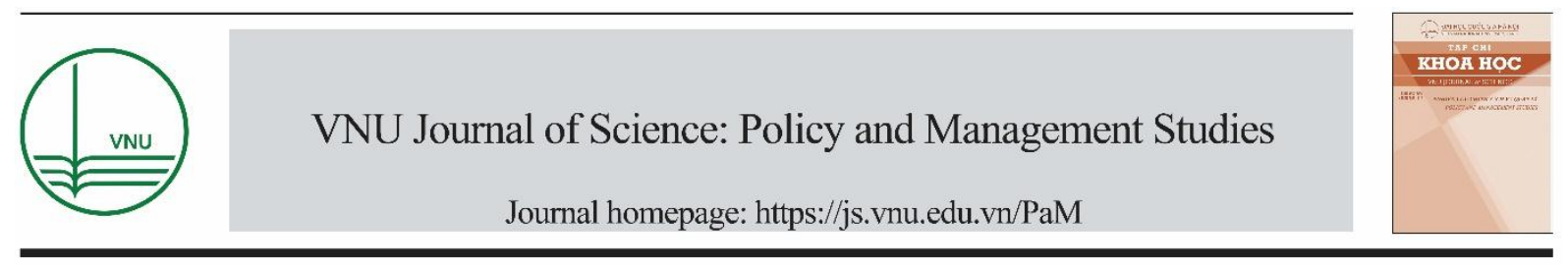

\title{
Vận dụng lý thuyết "lực hút-đẩy" trong nghiên cứu di cư lao động tự do từ nông thôn ra thành thị tìm kiếm việc làm hiện nay ở Việt $\mathrm{Nam}^{1}$
}

\author{
Nguyễn Đình Tấn* \\ Học viện Chính trị Quốc gia Hồ Chỉ Minh, 135 Nguyễn Phong Sắc, Cầu Giấy, Hà Nội, Việt Nam \\ Nhận ngày 26 tháng 9 năm 2019 \\ Chấp nhận đăng ngày 30 tháng 9 năm 2019
}

\begin{abstract}
Tóm tắt: Lý thuyết lực hút-lực đẩy là một lý thuyết đã được kiểm nghiêm và áp dụng cho nhiều nghiên cứu về di dân. Trong khá nhiều các nghiên cứu đều cho thấy, có nhiều yếu tố thúc đẩy người di cư. Tuy nhiên, lý thuyết lực hút-lực đẩy vẫn là yếu tố xuyên suốt, có tác dụng chi phối các yếu tố khác. Những nghiên cứu về di cư lao động tự do từ nông thôn ra đô thị tìm kiếm việc làm ở Việt Nam cũng không phải là ngoại lệ. Chính những lực "hút" của nơi đến và lực "đẩy" của nơi đi, nơi có nhiều khó khăn, vất vả của người sở tại đã tạo ra dòng di chuyển dân cư trong xã hội. Điều này "xưa" như trái đất, đòi hỏi các cấp lãnh đạo Đảng và chính quyền cần có sự nhìn nhận và thái độ ứng xử đúng đắn, thích hợp. Giải quyết một cách đúng đắn và thích hợp nhất cho vấn đề di dân nói chung cho mọi hình thức di dân hiện nay là phải đầy mạnh công nghiệp hóa, hiện đại hóa, thu hẹp dần khoảng cách giữa các vùng, tiến tới một xã hội hài hòa,công bằng bình đẳng và thịnh vượng cho tất cả người dân.
\end{abstract}

Từ khóa: Di dân, di dân nông thôn - đô thị, "lực hút-lực đẩy", công nghiệp hóa, đổi mới thể chế.

\section{1. Đặt vấn đề}

Nghiên cứu di dân nói chung, di dân của lao động tự do từ nông thôn ra đô thị tìm kiếm việc làm hiện nay ở Việt Nam nói riêng là những hiện tượng phổ biến được rất nhiều các cơ

\footnotetext{
*Tác giả liên hệ.

Địa chỉ email:nguyenanhtanxhh@gmail.com

https://doi.org/10.25073/2588-1116/vnupam.4198

${ }^{1}$ Bài báo này được dựa trên các luận cứ, chứng cứ chủ yếu từ đề tài cấp Nhà nước: "Di dân các dân tộc thiểu số, những vấn đề đặt ra và giải pháp”
}

quan, tổ chức và cá nhân tiến hành nghiên cứu. Các nghiên cứu này cắt nghĩa và chỉ ra nhiều nguyên nhân khác nhau dẫn đến di cư. Song cho dù có chỉ ra hay nhấn mạnh đến một nguyên nhân, nhóm nguyên nhân (kể cả những nguyên nhân đặc thù như lý do kích động dân tộc, tôn giáo, lý do lôi kéo, dụ dỗ về mặt chính trị của những lực lượng thù địch hay tập quán lạc hậu hàng nghìn năm chi phối đến hành vi di dân của một dân tộc nào đó thì chúng ta cũng phải thừa nhận rằng, lý do "lực hút-lực đẩy"vẫn là lý do quan trọng nhất, thường xuyên nhất, xuyên suốt nhất và chi phối các nguyên nhân 
khác. Nghiên cứu này được tổng kết, khái quát từ chính cuộc nghiên cứu mà tác giả đang tiến hành, đồng thời tổng tích-hợp nhiều nghiên cứu định tính, định lượng khác (các tài liệu văn bản, bài báo, sách chuyên khảo về di dân). Tác giả mong được các quý khán giả, quý bạn đọc chia sẻ, đồng tình, ủng hộ và có những tham góp quý giá.

\section{Vài nét về lý thuyết "Lực hút-lực đẩy"}

Nghiên cứu di cư lao động tự do từ nông thôn ra thành thị trong bối cảnh của đổi mới, công nghiệp hóa, đô thị hóa, hiện đại hóa và hội nhập quốc tế nằm trong bối cảnh của di dân nói chung ở Việt Nam. Vì vậy, nó cũng bị chi phối bởi các quy luật chung. Ngoài những nét riêng biệt, đặc thù của chỉ riêng từng vùng, loại hình di cư thì quy luật "lực hút lực đẩy" là yếu tố chủ yếu có thể cắt nghĩa một cách phổ biến cho căn do của hiện tượng di dân (di cư). Lý thuyết "lực hút lực đẩy" có nguồn gốc từ Everett Lee (1966). Lý thuyết này xem xét di dân của dân cư như sự thay đổi nơi cư trú trong những bối cảnh nhất định, nhấn mạnh rằng, di cư là kết quả của sự tương tác giữa các nhân tố hút và nhân tố đẩy có mặt ở cả nơi đến, nơi xuất phát, các yếu tố can thiệp và các yếu tố cá nhân [1, tr.47-57]. Đó là quá trình bị chi phối bởi "sức hút" của nơi đến và "lực đẩy" của nơi đi. Everett Lee đã luận giải rẳng, do "lực đẩy" của nơi ở, nơi có nhiều khó khăn, vất vả của người sở tạị (nơi xuất cư) và do "lực hút" của nơi đến (nơi nhập cư) có nhiều thuận lợi hơn, cơ hội sống và làm việc tốt hơn đã khách quan tạo ra sự luân chuyển của các dòng di $\mathrm{cư}^{2}$.

Tiếp theo lý thuyết này còn có nhiều học giả khác đã phát triển và bổ sung, khai thác nhiều khía cạnh làm phong phú thêm lý thuyết và làm cho lý thuyết đó càng có thể ứng dụng

\footnotetext{
$\overline{2}$ Trích lược từ Báo cáo tổng hợp kết quả nghiên cứu của đề tài khoa học và công nghệ cấp tỉnh năm 2015 . Tên đề tài: Di cư xuyên biên giới của các dân tộc thiểu số ở tỉnh Điện Biên - Thực trạng và giải pháp can thiệp chính sách của PGS.TS. Đoàn Minh Huấn (tr. 3-4).
}

một cách phổ dụng trong những điều kiện và hoàn cảnh đa dạng khác. Có thể kể tên tác giả tiếp theo như Todaro (1971). Theo Todaro, người di cư đã chuyển đến nơi ở mới có điều kiện kinh tế tốt hơn. Tùy theo điều kiện, khả năng của cá nhân/ nhóm mà họ di chuyển tới một khu vực nông thôn hoặc đô thị, ở đó có điều kiện kinh tế tốt hơn hay có cơ hội thu nhập cao hơn. Từ lý thuyết của Todaro có thể giải thích được tại sao khu vực Tây Nguyên hay khu vực các đô thị lớn là những khu vực chính thu hút những người di cư ở Việt Nam. Tiếp theo lý thuyết của Toddro là lý thuyết "tính tuyển chọn" của P.Shaw (1972). Theo P.Shaw, sự khác biệt nhân khẩu-xã hội luôn hiện hữu và cần được đặc biệt chú ý khi xét mô hình và đặc trưng di dân. Tính tuyển chọn của di dân cần được lưu ý, xem xét trong các chính sách nhằm can thiệp vào quá trình này. Kết quả hai cuộc khảo sát trên phạm vi quốc gia cho thấy, những người di cư ở nước ta trong gần 20 năm qua có xu hướng là những người ở độ tuổi trẻ, chưa lập gia đình. Nữ giới có xu hướng di cư nhiều hơn nam giới. Những người có trình độ học vấn cao hơn có xu hướng di chuyển nơi cư trú nhiều hơn và họ hướng tới các khu vực đô thị nhiều hơn so với những người có học vấn thấp hơn.

Tiếp theo các lý thuyết vừa đề cập, còn phải kể đến lý thuyết của A.Rogers và L.J.Castro. Các mô hình di dân ở nước ta có điểm tương đồng với các kết quả nghiên cứu của A.Rogers và L.J.Castro (1981) về quy luật và lược đồ của di dân theo cơ cấu nhóm tuổi và giới tính, đạt đỉnh điểm ở độ tuổi 24-25 và 25-29, rồi sau đó giảm dần và giảm nhanh sau tuổi nghỉ hưu, dao động mạnh vào cuối vòng đời, đặc biệt là đối phụ nữ cao tuổi. Học vấn và nhận thức về cơ hội kinh tế là vấn đề đằng sau sự khác biệt dân số này.

Có thể nói rằng, tiếp theo lý thuyết gốc của Everett Lee về hút đẩy còn có nhiều biến thể khác nhau, khai thác, phản ánh nhiều khía cạnh khác nhau làm phong phú thêm lý thuyết và làm cho lý thuyết đó càng trở nên phổ dụng trong những điều kiện và hoàn cảnh đa dạng v.V...

Có thể diễn đạt một cách tóm tắt những nội dung chính của lý thuyết "hút-đẩy" như sau: 
Các yếu tố hút, "lục kéo" bao gồm:

- Các nước phát triển hoặc các khu vực thành phố công nghiệp hóa trong các quốc gia tạo "lực kéo" các quốc gia và khu vực chậm phát triển, thu nhập thấp, nền kinh tế lạc hậu, cuộc sống còn gặp nhiều khó khăn.

- Ở các quốc gia có phương tiện thông tin hiện đại: có hệ thống điện thoại, Internet, mạng xã hội thuận tiện làm cho việc truy cập, trao đồi thông tin trở nên dễ dàng hơn khiến cho con người trao đổi, giao dịch trong công việc cũng như trong đời sống, sinh hoạt tiện ích hơn tạo lực "hút" cho hành động di dân.

- Sự thiếu hụt lao động do sự góp phần của tỷ lệ sinh liên tục giảm ở một số quốc gia như: Đức, Nhật v.v...

- Ở các nước kinh tế phát triển đi đôi với chế độ phúc lợi xã hội cao như: Thụy điển, Đan Mạch Na Uy, Phần lan v.v...

- Ở những nơi mà có nền dân chủ tiến bộ, nơi mà tự do tôn giáo và quyền con người được đề cao cũng thường là "lực hút" đối với cư dân của nhiều quốc gia còn bị o ép, hạn chế trong lĩnh vực này.

Các quốc gia tiếng Anh phổ biến cũng là lực hút lớn đối với nhiều nam nữ thanh niên .

- Những người đang độ tuổi đi học di cư để có được cơ hội học hành nâng cao trình độ học vấn, kỹ năng làm việc và những việc làm tốt hơn ở nơi đang sinh sống. nhập thấp.

- Các yếu tố "lực đẩy": Nghèo đói và thu

- Thiếu triển vọng phát triển nghề nghiệp.

- Thiếu đất canh tác, địa hình chia cắt, thiếu tài nguyên đất đai.

- Tỷ lệ thất nghiệp cao, thiếu việc làm.

- Tồn tại phổ biến những vấn nạn xã hội và không đảm bảo về mặt nhân quyền.

- Xung đột nội bộ và chiến tranh.

- Thiên tai, biến đổi khí hậu ngày một xấu đi, nạn đói, cướp giật tràn lan v.v...

\section{Di cư lao động tự do từ nông thôn ra thành thị tìm kiếm việc làm hiện nay ở Việt Nam dưới tác động của lý thuyết lực hút lục đẩy}

Thực tiễn cho thấy, trực trạng di cư ở các địa phương trên khắp đất nước ta từ thành phố Hà Nội, TP. Hồ Chí Minh cho đến các tỉnh lẻ kém phát triển kinh tế xã hội hơn như Nghệ An, Thanh Hóa, Khánh Hòa, Cà Mau, Hải phòng, Hải Dương v.v... đều bị chi phối mạnh mẽ bởi quy luật "lực hút-lực đẩy". Nghiên cứu cho thấy, người lao động di cư đều nhằm vào nhiều mục đích khác nhau và đều được cải thiện đáng kể về mức sống trong đó quan trọng nhất là mục tiêu kinh tế. Trong luận án nghiên cứu của NCS. Đoàn Thanh Trường, Học viện KHXH, Viện Hàn lâm KH\&XH Việt Nam, với 385 người được hỏi, đã có $96,9 \%$ người cho rằng, mục đích di cư là để thoát nghèo; $91,2 \%$ cho rằng, di cư để kiếm tiền xây dựng, sửa sang nhà cửa; $82,9 \%$ cho rằng, mục đích của di cư là để có tiền chữa bệnh cho người thân; $78,4 \%$ cho rằng mục đích của di cư là để nuôi con cái ăn học; $56,9 \%$ là để có vốn làm ăn [2].

Theo tổng điều tra di cư nội địa Việt Nam năm 2015 cũng như nhiều cuộc điều ra nhỏ lẻ khác cũng cho thấy, luồng di cư từ nông thôn ra đô thị chiếm tỷ lệ lớn nhất trong các luồng di cư trong cả nước, hơn $50 \%$ người di cư lựa chọn đô thị là điểm đến [3]. Một cuộc điều tra di cư mùa vụ ở Hải Phòng cho biết: có $64,3 \%$ người di cư mùa vụ lựa chọn là nội thành Hải Phòng, $17 \%$ di cư đến các thị xã, thị trấn lân cận; thu nhập vẫn là yếu tố then chốt trong các quyết định di cư [4]. Vai trò kinh tế được đánh giá cao. Phần lớn người di cư cũng như những người sống trong cộng đồng đều nhận định về những đóng góp của người di cư là tương đối nhiều, giúp các gia đình có điều kiện để đầu tư, mua sắm nhiều vật dụng có giá trị [5].

Một cuộc nghiên cứu đề tài: "Di dân các dân tộc thiểu số. Thực trang và giải pháp" (Chương trình khoa học công nghệ cấp quốc gia giai đoạn 2016-2020: "Những vấn đề cơ bản và cấp bách về dân tộc thiểu số ở Việt Nam đến năm 2030"), do Giáo sư, Tiến sĩ Nguyễn Đình 
Tấn làm chủ nhiệm cũng cho thấy: Xu hướng di dân của đồng bào dân tộc thiểu số có lý do chủ yếu là thiếu đất canh tác, đất đai cằn cỗi, địa hình chia cắt, thiếu việc làm, nhiều khó khăn trong sinh kế (lực đẩy). Người Hmong, người Thổ, người Dao, Tày, Nùng... đều vì mục đích cải thiện cuộc sống. Họ đều vì những áp lực của nơi sống sở tại muốn được đi đến nơi ở mới có nhiều thuận lợi hơn, sinh kế tốt hơn (lực hút). Thực tế, tỷ lệ nghèo của người dân tộc thiểu số ở địa phương còn khá cao, lao động bị dôi dư còn khá nhiều, nhất là lao động nữ. trong khi đó, kinh tế thị trường ở nước ta lại cần nhiều đến lao động nữ. Những ngành nghề như da giầy, dệt may, lắp ráp linh kiện điện tử v.v... là những ngành nghề lại thích hợp và cần đến lao động nữ. Thực tiễn cho thấy, ngay cả khi phụ nữ di cư vì lý do gia đình thì mục đích chung của cả nam và nữ (hai vợ chồng) chủ yếu vẫn là cải thiện cuộc sống (tức là vẫn tuân theo quy luật "lực hút, lực đẩy") [5]. Đề xuất một số giải pháp nhằm hoàn thiện chính sách về di cư lao động tự do ở Việt Nam hiện nay:

+ Đẩy mạnh công nghiệp hóa, hiện đại hóa nông nghiệp, nông thôn, hoàn thiện công cuộc vận động xây dựng nông thôn mới

Đại hội Đảng lần thứ XI đã chỉ rõ: "Phát triển nông-lâm-ngư nghiệp toàn diện theo hướng công nghiêp hóa, hiện đại hóa gắn với vấn đề nông dân, nông thôn"; "Phát triển kinh tế-xã hôi hài hòa các vùng đô thị và nông thôn... để các vùng đều phát triển, từng bước giảm bớt chênh lệch về trình độ phát triển và mức sống dân cư giữa các vùng" [6]. Trong thời gian gần đây Đảng và Nhà nước ta đề ra chủ trương và cuộc vận động xây dựng nông thôn mới, đổi mới, quy hoạch phát triển nông thôn gắn liền với phát triển các khu đô thị mới, sắp xếp bố trí lại dân cư.

Tuy nhiên những biến đổi vẫn chưa tương xứng với kỳ vọng. Đời sống của người nông dân, nhất là nông dân miền núi, vùng xa, vùng sâu, vùng dân tộc thiểu số còn gặp nhiều khó khăn, chưa theo kịp miền xuôi, thị trấn, thị xã, thành phố. Trình độ phát triển giữa các vùng còn cách biệt lớn và chưa có dấu hiệu thu hẹp.
Sự cách biệt lớn giữa nông thôn và đô thị đã tao nên lực "hút-đẩy" của các dòng di cư nông thôn-đô thị nhất là di cư từ nông thôn ra các thành phố lớn.

Để quản lý một cách hiệu quả dòng di dân tự do nông thôn-đồ thị hiện nay ở Việt Nam nói chung, di dân đến các thành phố lớn nói riêng thì vấn đề trước tiên mang tính nền tảng, lâu dài là quán triệt đẩy đủ hơn nữa các chủ trương, chính sách của Đảng và Nhà nước về phát triển kinh tế- xã hội, đẩy mạnh công nghiệp hóa, hiện đại hóa nông nghiệp, nông thôn, xóa dần sự cách biệt giữa nông thôn và đô thị, xây dựng các thành phố vệ tinh, cụm dân cư theo hướng thị trấn, thị xã (đô thị hóa tại chỗ; ly nông bất ly hương), làm cho nông thôn xích dần đến thành thị; làm cho thanh niên nông thôn khônng thấy mình bị bỏ lại, lạc hậu, lạc lõng trước mọi cơ hội lập thân, lập nghiệp, yên tâm sống và làm việc trên địa bàn nông thôn; hơn thế nữa, sự biến đổi tích cực của nông thôn còn tạo ra "lực hút" đối với những người đã di cư trở lại quê nhà làm ăn, sinh sống.

Công nghiệp hóa nông nghiệp, nông thôn là quá trình chuyển người nông dân từ làm ăn nhỏ lẻ, manh mún thành người công nhân nông nghiệp, hiệp hội, hợp tác, sản xuất theo "chuỗi"; tránh được mọi rủi ro, "được mùa mất giá", "được giá mất mùa" với điệp khúc giải cứu lặp đi lặp lại đến nhàm chán. Trên thực tế, nhiều địa phương, công nghiệp hóa đã đạt được những thành tựu quan trọng, làm tăng năng suất lao động, cải thiện một cách đáng kể cuộc sống người dân. Tuy nhiên, song hành với những thành tựu đáng khích lệ đã đạt lại đồng thời xuất hiện tình trạng lao động "dư thừa", thời gian "nông nhàn" tăng lên, tạo "lực đẩy" mới cho dòng di dân tự do nông thôn-đô thị. Và bởi vậy, quá trình công nghiệp hóa nông nghiệp, nông thôn đã không mạng lại thành tựu một cách một chiều mà còn để loại những hệ lụy của nó đòi hỏi phải đồng thời phải đẩy mạnh hơn nữa sự nghiệp dạy nghề, tạo ra những công việc phù hợp để giải quyết vấn đề lao động "dư thừa" trong thời gian "nông nhàn" của người dân. 
Thục hiện công nghiệp hóa, công nghiệp hóa nông thôn đòi hỏi phải hình thành mới hàng ngàn khu công nghiệp, khu chế xuất, cụm dân cư mới kèm theo; theo đó là hàng nghìn hecta đất nông nghiệp bị chuyển đổi mục đích sử dụng, một số lượng lớn lao động ở nông thôn không có việc làm. Đất bị thu hẹp, rất ít lao động địa phương được tuyển dụng vào làm việc tại chỗ (tại các doanh nghiệp), làm gia tăng tình trạng thiếu việc làm ở các địa phương. Chính thực trạng đó đã khách quan tạo "lực đẩy"người dân nông thôn di cư tự do ra khu vực đô thị để tìm kiếm việc làm, cải thiện đời sống. Đến lượt nó, quá trình công nghiệp hóa, hiện đại hóa lao động nông nghiệp, nông thôn đòi hỏi phải tạo nhiều công việc mới để thu hút lao động "dư thừa" tương đối ở nông thôn. Trong những năm tới, Đảng, Nhà nước có chủ trương, kế hoạch thành lập các thành phố "vệ tinh" đồng thời chuyển rời một số trường đại học, cao đẳng ở các thành phố lớn ra khu vực ngoại thành hoặc các tỉnh lân cận, theo đó sẽ góp phần giải tỏa áp lực dân cư, tạo "lực hút" đối với cư dân nông thôn, giảm thiểu số lượng và cường độ di dân tự do.

+ Đảm bảo an sinh xã hội khu vực nông thôn

Tại văn kiện đại hội Đảng lần thứ XII, Đảng ta chủ trương phát triển kinh tế xã hội gắn với thực hiện tiến bộ xã hội và công bằng xã hội [7, tr.132], giải quyết tốt lao động việc làm và thu nhập cho người lao động, đảm bảo an sinh xã hội [7, tr.136], tiếp tục hoàn thiện chính sách an sinh xã hội phù hợp với quá trình phát triển kinh tê- xã hội [7, tr.137]. Mở rộng đối tượng và nâng cao hiệu quả của hệ thống an sinh xã hội đến mọi người dân; tạo điều kiện để trợ giúp có hiệu quả cho tầng lớp yếu thế, dễ tổn thương gặp những người rủi ro trong cuộc sống. Phát triển và thực hiện tốt các chính sách bảo hiểm xã hội, bảo hiểm thất nghiệp, bảo hiểm tai nạn lao động... Chuyển từ chố nhân đạo sang bảo hiểm quyền an sinh xã hội của công dân. Đổi mới chính sách giảm nghèo theo hướng tập trung, hiệu quả và tiếp cận phương pháp đo lường nghèo đa chiều nhằm bảo đảm an sinh xã hội cơ bản và tiếp cận các dịch vụ xã hội cơ bản. Tổ chức tốt hơn việc cung cấp các dịch vụ cơ bản, thiết yếu. Thực hiện tốt các chính sách hỗ trợ nhà ở cho các đối tượng chính sách người nghèo, nhân dân sống ở vùng xa, vùng sâu, vùng khó khăn; phát triển nhà ở xã hội cho người thu nhập thấp, công nhân khu công ngiệp, khu chế xuất và sinh viên...Phát triển đa dạng các hình thức từ thiện, đẩy mạnh phong trào toàn dân tham gia giúp đỡ những người yếu thế.

Về bảo hiểm xã hội: Cần chú trọng tăng tỷ lệ người lao đông tham gia bảo hiểm xã hội; đẩy mạnh xã hội hóa dịch vụ bảo hiểm; đảm bảo đúng, đủ chế độ quy định về mọi đối tượng. Về trợ giúp và cứu trợ xã hội: tiến hành đa dạng, linh hoạt; bảo vệ, giúp đỡ mọi thành viên trong xã hội, đặc biệt là nhóm xã hội yếu thế. Về các chương trình xã hội: Tập trung triển khai có hiệu quả các chương trình xóa đói giảm nghèo; tạo điều kiện để xóa đói giảm nghèo bền vững, giúp người nghèo vươn lên thoát nghèo, một bộ phận trở thành người giàu và đến lượt họ lại giúp những người khác thoát nghèo. Cần huy động mọi nguồn lực trong đó Nhà nước làm trung tâm, chăm lo tốt hơn nữa đời sống của mọi người dân nhất là những gia đình có công; giải quyết dứt điểm những tồn đọng cho những gia đình chính sách sau chiến tranh.

Trong chính sách an sinh xã hội với toàn dân nói chung, cần tập trung vào bảo hiểm xã hội cho nông dân, trợ giúp kịp thời hiệu quả, đúng và đủ cho người dân khi họ gặp phải rủi ro, thiên tai, dịch họa, giúp họ kịp thời khôi phục lại sản xuất, phát triển kinh tế xã hội... Chính thông qua các hoạt động thiết thực, hiệu quả như vậy sẽ giúp người nông dân yên tâm sản xuất, sinh sống, trụ vững ở quê nhà, hạn chế việc di dân đến khu vực đô thị để sịnh sống

+ Tiếp tục hoàn thiện thể chế, hệ thống chính sách, pháp luật quản lý di dân tự do

Về việc ban hành các văn bản pháp quy quản lý di dân

Quản lý xã hội nói chung, quản lý di cư nói riêng phải luôn luôn dưạ trên các văn bản pháp luật. Việc ban hành các văn bản pháp luật, hệ thống chính sách nhằm quản lý có hiệu quả di dân tự do là một yêu cầu khách quan, cần thiết 
trong quá trình hoàn thiết Nhầ nước pháp quyền xã hội chủ nghĩa. Theo yêu cầu đó cần có một đạo luật về di dân nói chung, di dân tự do nói riêng. Trước tiên là các văn bản quy định về quyền di cư (trong hiến pháp đã có) nhưng cần quy định cụ thể. Nói rõ trách nhiệm, nghĩa vụ và quyền lợi của người di dân. Quyền lợi phải được gắn chặt với trách nhiệm, nghĩa vụ. Điều này cần được đề cập đến cả người di cư và chính quyền; cả nơi đi và nơi đến; cần nói rõ cả quyền sở hữu tài sản, quyền sở hữu về tư liệu sản xuất, đất đai. v.v...

Trong bối cảnh của mở cửa, kinh tế thị trường rất cần sớm có các văn bản pháp luật nói chung về di dân nói riêng để Nhà nước quản lý hiệu quả công dân của mình trong đó có hiện tượng di dân "tự do" nhằm đảm bảo xã hội trật tự, ổn định và phát triển bền vững.

Tổ chức đăng ký và cấp thẻ lao động cho ngườ di dân tư do nông thôn-đô thi

Quản lý di cư không đơn giản là cấm đoán, xiết chặt kiểm soát hay ngăn chặn dòng di dân tự do nông thôn-đô thị. Để quản lý một cách văn minh, phù hợp với pháp luật quốc tế, cần phải ban hành các quy chế về quản lý lao động, tổ chức đăng ký và cấp thẻ lao động cho nững người di cư tự do nông thôn-đô thị. Về thực chất, những người di cư tự do nông thôn-đô thị là những người lao động từ khu vực nông thôn ra khu vực đô thị để tìm kiếm việc làm. Bởi vậy, việc ban hành các quy chế đăng ký và cấp thẻ lao động là biện pháp thức thời nhằm có thể quản lý hiệu quả nhóm xã hội này. Trong bối cảnh của Nhà nước kiến tạo, Nhà nước dịch vụ, Nhà nước đồng hành với người dân trong mọi hành động, việc làm thì việc ban hành các văn bản pháp luật như vậy sẽ là một sự thích hợp cần thiết. Tuy nhiên cùng với những hiệu quả tích cực như chúng ta vừa đề cập thì việc ban hành các văn bản như vậy cũng phần nào tăng thêm sự phức tạp cho công tác quản lý (nhất là trong trường hợp bị lạm dụng). Vì vậy các nhà quản lý cũng như cơ quan chức năng cần vận dụng rất nhạy bén, linh hoạt với từng trường hợp cụ thể.
Tiếp tục đổi mới công tác quản lý cu trú theo huớng gắn kết với quản lý hộ khẩu, hộ tịch, thẻ căn cuơóc công dân

Quản lý theo hướng gắn kết với công tác hộ khẩu, hộ tịch, căn cước công dân là một trong những nhiệm vụ quan trọng trong công tác cải cách thủ tục hành chính đáp ứng nguyện vọng chính đáng của nhân dân cũng như xu hướng khách quan của mở cửa, hội nhập quốc tế, toàn cầu hóa. Làm tốt công việc này sẽ giảm thiểu các phiền hà cho người di cư tự do, góp phần lành mạnh và văn hóa, văn minh xã hội. Trong quá trình triển khai thực hiện cần chú trọng tuyên truyền, vận động, giải thích cho người dân hiểu rõ những quyền lợi của người di cư; làm cho họ hiểu rõ rằng, việc kết hợp này sẽ đảm bảo an toàn xã hội và những tiện ích của việc kết hợp đó mang lại.

Cải cách thủ tục hành chính theo co chế "một cưa, thưc hiẹn dịch vu hành chính công trong đăng ký, quản lý cư trú

Quyết định 181/TTg ngày 4/9/2013 của Thủ tướng Chính phủ chỉ rõ: "Cơ chế một cửa sẽ trở thành công cụ phục vụ nhân dân tốt nhất, là mục tiêu cải cách của nền hành chính nhà nước".

Thực hiện cơ chế cải cách thủ tục hành chính theo hướng công khai, minh bạch, thủ tục hành chính đơn giản, giảm thiểu phiền hà, tạo điều kiện thuận lợi cho công dân. Để thực hiện nội dung cải cách thủ tục hành chính theo cơ chế "một cửa" cần tập trung làm tốt việc tuyên truyền cho cán bộ trực tiếp thực hiện đăng ký quản lý cư trú có ý thức công vụ phục vụ nhân dân và nâng cao đạo đức nghề nghiêp. Đồng thời chú trọng tuyên truyền cho nhân dân nhất là những người di dân tự do về ý nghĩa của việc cải cách hành chính theo mô hình "một cửa" để họ tự giác thực hiện việc đăng ký tạm trú, tạm vắng. Sự nghi ngờ hay nhận thức còn mơ hồ về cơ chế "một cửa" sẽ là một trở ngại cho việc quản lý hộ khẩu, nhân khẩu dẫn đến khó khằn trong việc kiểm soát soát dòng di dân tự do từ nông thôn ra đô thị. 
Thực hiện tốt việc đăng ký hộ chiếu, hộ tịch và hộ khẩu cho cu dân Việt Nam tù nuớc ngoài trở về

Trong những người rời cư sang Lào, Cămpuchia, Mianma thời chiến tranh nay hồi hương ở các tỉnh Tây Ninh, Đồng Tháp, Kiên Giang... nhưng không có hộ khẩu, con em họ vì vậy không được nhập hoc, họ không được bảo hiểm, chăm sóc y tế và thụ hưởng một số chế độ, chính sách khác. Điều này dẫn đến xáo trộn và tâm lý e ngại của người hồi cư. Chính quyền sở tại cần đề xuất với các cơ quan chức năng, đổi mới công tác hộ tịch, hộ khẩu, kịp thời giải quyết một cách thích hợp nhằm nhanh chóng ổn định đời sống dân cư.

Đầu tu phưong tiện khoa hoc kỹ thuật, sủ dụng các thành tưu công nghệ thông tin vào công tác quản lý cư trú

Trong bối cảnh của cuộc cách mạng khoa học, công nghệ như vũ bão và sự ứng dụng ngày càng nhanh vào các lĩnh vực của đời sống xã hội rất cần ứng dụng công nghệ thông tin vào quản lý cư trú nói chung, quản lý cư trú đối với những người di dân tự do nông thôn-đô thị nói riêng.

Để tiến hành có hiệu quả quá trình này, cần phải triển khai đồng bộ các biện pháp: Một là: xây dựng cơ sở dữ liệu để tiếp nhận vừa đủ thông tin của các cá nhân để qua đó vừa bảo đảm quyền bí mật thông tin cá nhân (phù hợp với công ước quốc tế) vừa đủ những thông tin cần thiết cho việc nắm bắt được nhân thân mỗi người. Hai là: Xây dựng hệ thống phần mềm quản lý dữ liệu thông tin cá nhân trên phạm vi của quốc gia để có thể quản lý bất kỳ ai, bất cứ ở nơi đâu giúp quản lý cư trú một cách thuận tiện, mau lẹ, chính xác. $B$ a là: Tuyên truyền cho mọi người dân, trong đó là những người di dân tự do hiểu được tiện ích và ý nghĩa của việc số hóa nhân khẩu taọ điều kiện dễ dàng cho việc quản lý cư trú.

+ Tăng cường quản lý xã hội đối với di dân tụ do nông thôn-đô thị, hạn chế nhũ̃ng hành vi tiêu cực ảnh huởng đến trật tụ xã hội đô thị
Quản lý xã hội, về cơ bản là việc sử dụng bộ máy Nhà nước và dựa vào hệ thống pháp luật để quản lý mọi lĩnh vực hoạt động của đời sống xã hội (kinh tế, chính trị, văn hóa, xã hội, giáo dục, an ninh, quốc phòng, ngoại giao, v.v...) nhằm hướng mọi hoạt động này vào khuôn khổ pháp luật của Nhà nước.

Quản lý cư trú của công dân được xác định là một bộ phận của quản lý xã hội. Nội dung cơ bản của quản lý hành chính về trật tự an toàn xã hội về thực chất là quá trình quản lý hoạt động cư trú của con người.

Mục đích của quản lý cư trú là xác định quyền cư trú của công dân, đảm bảo cho công dân thực hiện quyền và nghĩa vụ của họ theo luật định; đáp ứng yêu cầu quản lý xã hội của Nhà nước, yêu cầu nghiệp vụ của các cơ quan chức năng nhằm phòng ngừa, đấu tranh chống tội phạm và các hành vi sai lệch xã hội khác.

Nội dung của công tác đăng ký quản lý cư trú gồm: đăng ký tạm trú, thường trú, tạm vắng, những thay đổi về hộ khẩu, nhân khẩu và xử lý vi phạm.

Quản lý cư trú của công dân là một công tác quan trọng để phục vụ cho công tác quản lý xã hội của Nhà nước, đảm bảo quyền tự do cư trú của công dân, nhằm tạo ra một xã hội văn minh, có kỷ cương, môi trường tự do, hoà bình, hội nhập quốc tế trong xu hướng toàn cầu hóa. Quản lý cư trú là cơ sở cho các cơ quan, tổ chức, lãnh đạo và các chính quyền địa phương xây dựng và thực hiện được cơ chế quản lý trúng và đúng, chủ động thu hút các nguồn lực để phát triển kinh tế-xã hội; xác định các giải pháp thiết thực có hiệu quả trong tình hình gia tăng di biến động dân cư. Thông qua quản lý cư trú mà có thể phân biệt được người tốt, kẻ xấu; từ đó khu biệt được các đối tượng trọng tâm trọng điểm để có được những biện pháp quản lý thích hợp; phòng ngừa, đấu tranh có hiệu quả; đồng thời vô hiệu hóa một cách kịp thời (ngay và đúng) các đối tượng tội phạm cũng như những kẻ xấu, lợi dụng để bôi bác chế độ.

Trong thời gian qua, quản lý di cư tự do nông thôn-đô thị ở nước ta tuy đã có một vài tiến bộ song còn khá nhiều bất cập. Vẫn còn 
tình trạng người di cư nơi đi không báo cáo tạm vắng cho chính quyền nơi đi cũng như báo cáo tạm trú cho chính quyền nơi đến. Ở đây có cả sự xem thường các quy định của pháp luật, thiếu thượng tôn pháp luật của người di cư, có cả sự buông lỏng, thiếu trách nhiệm của chính quyền địa phương ở nơi đi và đến. Các chế tài xử lý đối với những trường hợp người di cư vi phạm chưa đủ răn đe, chưa kịp thời trúng và đúng (nhờn luật); do đó vẫn còn có những công dân đứng "ngoài vòng pháp luật" gây khó khăn cho hoạt động quản lý.

Chính những yếu kém trong quản lý di cư làm tăng thêm các sai lệch xã hội, rối loạn trật tự xã hội, giao thông bị hỗn loạn, ách tắc, tai nạn giao thông gia tăng làm sự bất an của người dân.

+ Tăng cường, nâng cao vai trò giới cho cả nam và nũ trong tùng gia đình (cả nhũng người di cu cũng nhu người ở nhà)

Tăng cường giáo dục giới, bình đẳng giới trong gia đình và cộng đồng, làm tăng trách nhiệm của mỗi giới, giúp đỡ lẫn nhau, san sẻ, tương trợ lẫn nhau cũng như khả năng hoán đổi các vai trò giới khi cần thiết, khi phải đảm nhiệm những công việc mà người chồng hoặc người vợ vắng mặt.

Trong các loại hình di cư, có di cư mùa vụ nông thôn-đô thị. Thực chất, đó là một quá trình mang tính xã hội. Qua quá trình đó, người dân nông thôn tiếp xúc với nền văn minh đô thị và tích lũy co mình cả nguồn vốn vật chất cũng như những tri thức từ đô thị. Nguồn tích lũy đó được chuyển tải về địa phương, về gia đình mình thông qua những đóng góp của người di cư đối với phát triển kinh tế hộ gia đình.

Hoạt động sản xuất kinh doanh (chủ yếu của phân nửa số hộ gia đình có chồng di cư- vợ ở nhà, vai trò giới chuyển giao cho phụ nữ. Ngay cả khi cả hai vợ chồng cùng di cư, thì phần lớn các công việc sản xuất cũng thường do phụ nữ đảm nhận. Người chồng chủ yếu chỉ đảm nhận các công việc năng nhọc như cày bừa, phun thuốc trừ sâu; họ làm thay vợ các công việc khác khi vợ di cư nhưng có xu hướng mua hoặc thuê mướn lao động (làm những công việc mà họ kém thành thạo như gieo mạ, cấy).

Hoạt động nội trợ ở nhà trước và sau di cư đều do phụ nữ đảm nhận. Vì vậy khi đàn ông di cư, người phụ nữ dễ dàng thích nghi với những công việc này (những công việc vốn dĩ người phụ nữ khá quen thuộc). Nhưng ngược lại, khi phụ nữ di cư, ngưới chồng ở nhà chậm thích nghi hơn (thường phải trên dưới 1 tháng, họ mới dần thích nghi được).

Hoạt động chăm sóc con cái và cha mẹ già có người di cư. Trước khi gia đình có người di cư, hai vợ chồng tham gia vào hầu hết các loại công việc. Nhưng sau khi gia đình có người di cư mùa vụ, phần lớn các loại việc như chăm sóc và nuôi dạy con cái, hướng dẫn, giám sát con học hành, đi họp phụ huynh cho con, hỏi han, trò chuyện với bố mẹ già đều do người vợ (người phụ nữ) đảm nhận chính. Người chồng chủ yếu chỉ phụ giúp vợ trong viêc chăm sóc con cái lúc ốm đau và chu cấp kinh tế cho cha mẹ già. Trong việc chăm sóc con cái đã xuất hiện vai trò của ông bà nội ngoại hai bên. Cùng theo đó là vai trò của người thân (anh chị em nội ngoại hai bên) trong chăm sóc bố mẹ già.

Các công việc của dòng họ và cộng đồng, trước khi gia đình có người di cư mùa vụ, các cuộc họp họ, cúng giỗ, tham gia cac tổ đội sản xuất đều có sự chung sức của cả hai vợ chồng. Nhưng vai trò giới thay đổi chuyển dần sang người vợ khi gia đình có người di cư. Một số loại việc như (họp họ, hiếu hỉ) xuất hiện sự tham gia của người thân, họ hàng (chủ yếu là bố mẹ của vợ chồng hai bên).

Quyền quyết định các công việc trong gia đình diễn ra theo chiều hướng bình đẳng giới; Khi vắng mặt người chồng, người vợ có thể ra quyết định nhiều hơn; trong những trường hợp như vậy, phần lớn các quyết định do người ở nhà (người vợ) đảm nhiệm.

Việc sắp xếp, phân công lại lao động trong gia đình có người di cư mùa vụ rất thường xảy ra; họ rất dễ thường phải thay thế, hoán đổi cho nhau để thích ứng với hoàn cảnh. Bởi vậy, cần phải đẩy mạnh hơn nữa quan điểm và hành vi về bình đẳng giới trong từng hộ gia đình để có 
thể cùng nhau hoàn thành tốt mọi công việc một cách êm ả, có hiệu quả.

+ Việc đẩy mạh công tác bình đẳng giới không chi đối với người chồng, người vơ (nam giới và phu nũ nói chung trong tùng gia đình) mà còn cần phải có sự góp sức của chính quyền và cộng đồng

Truớc tiên và hết sức quan trong là vai trò của chính quyền: Các chính quyền sở tại cần tăng cường tuyên truyền, vận động cho công chức cũng như toàn dân về vai trò giới, bình đẳng giới. Giáo dục truyền thông về định kiến giới, phê phán những hủ tục về bất bình đẳng giới của quá khứ cũng như những tàn tích còn lưu truyền phổ biến trong xã hội; xây dựng những mô hình bình đẳng giới phong phú sáng tạo để mọi người cùng học tập, noi gương. Kiên quyết đấu tranh và có những chế tài nghiêm khắc để ngăn chặn, đẩy lùi tình trạng bất bình đẳng giới đang tồn tại ở đâu đó trong xã hội xung quanh. Cần kịp thời nêu gương, nhân rộng những hành động bình đẳng giới thiết thực, có ý nghĩa ra toàn cộng đồng. Ở đây, vai trò của các chi hội phụ nữ xã, phường cũng như vai trò của tổ đội phụ nữ xóm, thôn có một ý nghĩa thiết thực, cụ thể.

Cộng đồng cũng có một vai trò quan trong trong công tác nâng cao vai trò giới và công tác bình đẳng giới: Nếu công tác nâng cao vai trò giới và hoạt động giáo dục bình đẳng giới chỉ được tiến hành một cách đơn lẻ trong từng gia đình cũng như độc lập ở chính quyền thì không thể nào làm cho các hoạt động này chuyển biến một cách đầy đủ. Ở đây vai trò của dòng họ, hội phụ lão, các hiệp hội sản xuất, cây trồng có một ý nghĩa to lớn. Chính quần chúng là tai mắt nhạy bén và tinh tường nhất cho các cấp chính quyền; kịp thời phát hiện, tố giác những hành vi bất bình đẳng giới, vi phạm vai trò giới lẩn khuất trong các thôn, xóm, bản, làng mà thông thường rất ít khi bị lộ diện. Các cuộc họp thôn, xóm, tổ đội sản xuất, hay sinh hoạt trong các gia đình, dòng họ là nơi dễ dàng để phát giác, kiểm điểm những sai trái một cách linh hoạt và thích hợp nhất.

\section{Tài liệu tham khảo}

[1] Lee, ES., A Theory of Migration, Demography 3 (1966)47-57.

[2] Đoàn Thanh Trường, Biến đổi cơ cấu lao động nông thôn dưới tác động của di cư lao động hiện nay, Luận án tiến sĩ, Thư viện KHXH Viện Hàn lâm KHXH Việt Nam, Hà Nội, 2017.

[3] Tổng cục thống kê, Điều tra di cư nội địa quốc gia 2015 - Các kết quả chủ yếu, NXB Thống kê, Hà Nội, 2016.

[4] Nguyễn Thị Phương Thảo, Di cư mùa vụ Nông thôn- Đô thị trong gia đình có người di cư ở nông thôn Hải Phòng hiện nay, Thư viện học viện CTQG Hồ Chí Minh, 2017.

[5] Nguyễn Đình Tấn, Xu hướng di dân các dân tộc thiểu số từ giác độ lực hút lực đẩy, Tạp chí Lý luận chính trị, số 5/2018, tr. 73-76, 2018.

[6] Đảng Cộng sản Việt Nam, Văn kiện Đại hội đại biểu toàn quốc lần thứ XI, NXB. CTQG - Sự thật, Hà Nội, 2011.

[7] Đảng Cộng sản Việt Nam, Văn kiện Đai hội đại biểu toàn quốc lần thứ XII, Văn phòng Trung ương Đảng, Hà Nội, 2016. 